\title{
Assessment of carbon-phenolic-in-air chemistry models for atmospheric re-entry
}

\author{
Alexandre Martin* and Iain D. Boyd ${ }^{\dagger}$ \\ Department of Aerospace Engineering, The University of Michigan, Ann Arbor, MI, 48109, USA
}

\begin{abstract}
Recent and future re-entry vehicle designs use ablative material as the main component of the heat shield of their thermal protection system. In order to properly predict the behavior of the vehicle, it is imperative to take into account the gases produced by the ablation process when modeling the reacting flow environment. In the case of charring ablators, where an inner resin is pyrolyzed at a relatively low temperature, the composition of the gas expelled in the boundary layer is complex and might lead to thermal chemical reactions that cannot be captured with simple flow chemistry models. In order to obtain better predictions, a proper gas flow chemistry model needs to be included in the CFD calculations. The present paper proposes to compare three published reaction sets that are relevant to carbon-phenolic ablators, such as PICA, the ablative material that was used on the Stardust return capsule and that will be used on the entry vehicle of the Mars Science Laboratory (MSL). Because extensive differences are found in boundary layer composition and heat fluxes, both convective and radiative, a new model is proposed.
\end{abstract}

\section{Nomenclature}

\begin{tabular}{ll}
\multicolumn{2}{c}{ Symbols } \\
$D$ & Mass diffusion co \\
$\dot{m}$ & Mass rate \\
$p$ & Pressure \\
$T$ & Temperature \\
& \\
& Subscripts \\
$g$ & Gas blown \\
$n c$ & Next to the wall \\
$s$ & Species
\end{tabular}

$\begin{array}{ll}U, v & \text { Velocity } \\ Y & \text { Mass fraction } \\ \eta & \text { Distance normal to the wall } \\ \rho & \text { Density }\end{array}$

$\rho$ Density

\section{Introduction}

The Thermal Protection System (TPS) of a re-entry vehicle is one of the key components of its design. The materials used for the TPS can be classified into two main categories: ablative materials, as in the one used on Apollo missions, and non-ablative materials, such as the ceramic tiles used on the space shuttle. The former can also be divided into two sub-categories: charring (also know as pyrolyzing) and non-charring ablators. The theory behind the use of ablators is quite simple: the energy absorbed by the removal of material from the surface is not used to heat the TPS, thus keeping the vehicle at a relatively "cold" temperature. In the case of charring ablators, the ablative material is a resin which fills the pores of a

\footnotetext{
*Research Associate, AIAA Member

$\dagger$ James E. Knott Professor of Engineering, Associate Fellow AIAA.

Copyright (c) 2010 by Alexandre Martin, Iain D. Boyd. Published by the American Institute of Aeronautics and Astronautics, Inc. with permission.
} 
carbon matrix. Although the matrix might ablate, it usually does not, thus preserving the original geometry of the aerodynamic surface during re-entry.

In order to properly model the heat rates at the surface of the vehicle, the ablating boundary condition must take into account many phenomena: surface recession, wall temperature, blowing rates, gas composition, surface chemistry, etc. However, to account for the effects of the pyrolysis gas on the vehicle, the chemistry model of the flow field must include the reactions associated with the presence of this gas. Because ablation coupling is becoming an increasingly important research topic, ${ }^{1-7}$ the development of an accurate, yet usable, chemistry model is of great importance. Models have been proposed in the past ${ }^{8-10}$ but important reaction were not included, and some of the reactions rates were inappropriate or simply outdated.

This paper proposes to take a closer look at the existing chemistry models, and test them in the hypersonic CFD code LeMANS. First, three published chemistry models are presented, and the difference between them are highlighted. Then, using a representative, but extreme test case, they are evaluated by taking a closer look at the boundary layer composition as well as convective and radiative heat fluxes. The discrepancy between the results clearly shows the need to develop a more comprehensive chemistry model, as the one presented in Ref. 11, but that would still run efficiently in a CFD code.

\section{LeMANS: an unstructured three dimensional Navier-Stokes solver for hypersonic nonequilibrium aerothermodynamics}

\section{A. Overview}

LeMANS is a finite volume Navier-Stokes solver currently being developed at The University of Michigan. ${ }^{12-15}$ The code assumes that the rotational and translational energy modes of all species can be described by their respective temperatures $T_{r}$ and $T$, and that the vibrational energy mode of all species and the electronic energy can be described by a single temperature $T_{v e} \cdot{ }^{16}$ The latter is computed using the species vibrational energy, modeled as a harmonic oscillator. The viscous stresses are modeled assuming a Newtonian fluid, using Stokes' hypothesis, and the species mass diffusion fluxes are modeled using a modified version of Fick's law. Mixture transport properties are calculated using one of two models; the first uses Wilke's semi-empirical mixing rule with species viscosities calculated using Blottner's model and species thermal conductivities determined using Eucken's relation, and the other uses Gupta's mixing rule with species viscosities and thermal conductivities calculated using non-coulombic/coulombic collision cross section data. Heat fluxes are modeled according to Fourier's law for all temperatures. Finally, the source terms of the species conservation equations are modeled using a standard finite-rate chemistry model for reacting air in conjunction with Park's two-temperature model to account for thermal nonequilibrium effects on the reaction rates.

Numerically, the code has the capability to handle meshes containung any mix of hexahedra, tetrahedra, prisms and pyramids in 3D, or triangles and quadrilaterals in 2D. Numerical fluxes between the cells are discretized using a modified Steger-Warming Flux Vector Splitting which has low dissipation and is appropriate to calculate boundary layers. A point or line implicit method is used to perform the time integration. The code has been extensively validated against experimental data, and has also been compared to other similar codes such as NASA Ames' DPLR ${ }^{17}$ and NASA Langley's LAURA. ${ }^{18}$

To account for the coupling between the flow field and the material response, ablation is added to the CFD code; therefore, a modification to the surface boundary condition is necessary. The physical values at the wall are obtained by solving the conservation of momentum:

$$
p_{n c}+\rho_{n c} v_{n c}^{2}=p_{w}\left(\rho_{w}, T_{w}\right)+\rho_{w} v_{w}^{2}
$$

as well as the species surface mass balance equation:

$$
\rho_{w} D_{w s} \frac{\partial Y_{w s}}{\partial \eta}=\dot{m}\left(Y_{g_{s}}-Y_{w_{s}}\right)
$$

The surface energy balance equation is not solved in the present work as the wall temperature, blowing rates and blowing species are imposed and not calculated.

Once values are computed for the primitive variables, the conservative quantities in the ghost cells of the boundary are set such that the flux across the wall is the required blowing flux. This blowing boundary condition has been tested over a wide range of blowing rates, assuring the robustness of the implementation. 
Following the same methodology for the verification and validation of NASA Ames' DPLR code ${ }^{19}$ and NASA Langley's LAURA code ${ }^{20}$ the blowing boundary of LeMANS has also been verified and validated. ${ }^{7,21}$

\section{Chemistry models}

\section{A. Park's model ${ }^{8}$}

The first model used in the present comparison has been developed by Park in 2000. It uses 20 species and is largely based on the 11 species air model combined with parts of a reaction mechanism used for Mars entry. Although the model is numerically fast, as it only includes 23 reactions ( 5 dissociations reactions), it lacks species that might be important at certain re-entry conditions and TPS surfaces, such as $\mathrm{O}_{2}^{+}$and HCN. Certain key reactions, such as $\mathrm{NO}$ and $\mathrm{C}_{3}$ dissociation, were also not included. However, the model offers a complete and comprehensive set of data, such as collisional cross sections, surface reactions and equilibrium constant curve fits. The 24 reactions of this model are listed in Table 1 and the 20 species are:

$$
\text { C, O, N, H, CO, } \mathrm{C}_{2}, \mathrm{~N}_{2}, \mathrm{CN}, \mathrm{NO}, \mathrm{O}_{2}, \mathrm{H}_{2}, \mathrm{C}_{3}, \mathrm{C}_{2} \mathrm{H}, \mathrm{C}^{+}, \mathrm{O}^{+}, \mathrm{H}^{+}, \mathrm{N}^{+}, \mathrm{NO}^{+}, \mathrm{N}_{2}^{+}, \mathrm{e}^{-} \text {, }
$$

Table 1: Reactions for Park's 20 species chemistry model

\begin{tabular}{ccc|ccc}
\hline \hline$\#$ & Reactions & Reference \# & Reactions & References & \\
\hline 1 & $\mathrm{~N}_{2}+\mathrm{M} \rightleftharpoons 2 \mathrm{~N}+\mathrm{M}$ & Ref. 22 & 2 & $\mathrm{O}_{2}+\mathrm{M} \rightleftharpoons 2 \mathrm{O}+\mathrm{M}$ & Ref. 22 \\
3 & $\mathrm{C}_{2}+\mathrm{M} \rightleftharpoons 2 \mathrm{C}+\mathrm{M}$ & Ref. 23 & 4 & $\mathrm{CN}+\mathrm{M} \rightleftharpoons \mathrm{C}+\mathrm{N}+\mathrm{M}$ & Ref. 23 \\
5 & $\mathrm{H}_{2}+\mathrm{M} \rightleftharpoons 2 \mathrm{H}+\mathrm{M}$ & Ref. 24 & 6 & $\mathrm{~N}+\mathrm{e}^{-} \rightleftharpoons \mathrm{N}^{+}+\mathrm{e}^{-}+\mathrm{e}^{-}$ & Ref. 22 \\
7 & $\mathrm{O}+\mathrm{e}^{-} \rightleftharpoons \mathrm{O}^{+}+\mathrm{e}^{-}+\mathrm{e}^{-}$ & Ref. 22 & 8 & $\mathrm{C}+\mathrm{e}^{-} \rightleftharpoons \mathrm{C}^{+}+\mathrm{e}^{-}+\mathrm{e}^{-}$ & Ref. 8 \\
9 & $\mathrm{H}+\mathrm{e}^{-} \rightleftharpoons \mathrm{H}^{+}+\mathrm{e}^{-}+\mathrm{e}^{-}$ & Ref. 8 & 10 & $\mathrm{~N}_{2}+\mathrm{O} \rightleftharpoons \mathrm{NO}+\mathrm{N}$ & Ref. 25 \\
11 & $\mathrm{NO}+\mathrm{O} \rightleftharpoons \mathrm{O}_{2}+\mathrm{N}$ & Ref. 26 & 12 & $\mathrm{CO}+\mathrm{C} \rightleftharpoons \mathrm{C}_{2}+\mathrm{O}$ & Ref. 23 \\
13 & $\mathrm{CO}+\mathrm{O} \rightleftharpoons \mathrm{O}_{2}+\mathrm{C}$ & Ref. 23 & 14 & $\mathrm{CO}+\mathrm{N} \rightleftharpoons \mathrm{CN}+\mathrm{O}$ & Ref. 23 \\
15 & $\mathrm{~N}_{2}+\mathrm{C} \rightleftharpoons \mathrm{CN}^{2} \mathrm{~N}$ & Ref. 23 & 16 & $\mathrm{CN}+\mathrm{O} \rightleftharpoons \mathrm{NO}+\mathrm{C}$ & Ref. 23 \\
17 & $\mathrm{CN}+\mathrm{C} \rightleftharpoons \mathrm{C}_{2}+\mathrm{N}$ & Ref. 23 & 18 & $\mathrm{CO}+\mathrm{C}_{2} \rightleftharpoons \mathrm{C}_{3}+\mathrm{O}$ & Ref. 8 \\
19 & $\mathrm{C}_{3}+\mathrm{N} \rightleftharpoons \mathrm{CN}+\mathrm{C}_{2}$ & Ref. 8 & 20 & $\mathrm{C}+\mathrm{C}_{3} \rightleftharpoons \mathrm{C}_{2}+\mathrm{C}_{2}$ & Ref. 8 \\
21 & $\mathrm{C}_{2} \mathrm{H}+\mathrm{H} \rightleftharpoons \mathrm{C}_{2}+\mathrm{H}_{2}$ & Ref. 8 & 22 & $\mathrm{O}+\mathrm{N} \rightleftharpoons \mathrm{NO}^{+}+\mathrm{e}^{-}$ & Ref. 22 \\
23 & $\mathrm{~N}+\mathrm{N} \rightleftharpoons \mathrm{N}_{2}^{+}+\mathrm{e}^{-}$ & Ref. 22 & & \\
\hline \hline
\end{tabular}

\section{B. Abe's model ${ }^{9}$}

The second model studied here was created for the pre-flight analysis of the MUSES-C (now called Hayabusa) re-entry vehicle, ${ }^{9}$ and uses 26 species and 50 reactions (12 dissociations). A key issue with this model is that it is mainly based on rates that date from the late 1960s to the late 1980s. ${ }^{27-31}$ It also lacks certain species that are important at some flight conditions of high-speed carbon-phenolic TPS entries, such as $\mathrm{H}^{+}$. The reactions of this model are listed in Table 2, and the species are:

$$
\begin{gathered}
\mathrm{C}, \mathrm{O}, \mathrm{N}, \mathrm{H}, \mathrm{CO}, \mathrm{C}_{2}, \mathrm{~N}_{2}, \mathrm{CH}, \mathrm{CN}, \mathrm{NO}, \mathrm{O}_{2}, \mathrm{H}_{2}, \mathrm{CO}_{2}, \mathrm{C}_{3}, \mathrm{C}_{2} \mathrm{H} \\
\mathrm{HCN}, \mathrm{HCO}, \mathrm{C}_{2} \mathrm{H}_{2}, \mathrm{C}^{+}, \mathrm{O}^{+}, \mathrm{N}^{+}, \mathrm{NO}^{+}, \mathrm{N}_{2}^{+}, \mathrm{CO}^{+}, \mathrm{O}_{2}^{+}, \mathrm{e}^{-}
\end{gathered}
$$

Table 2: Reactions for Abe's 26 species chemistry model

\begin{tabular}{ccc|ccc}
\hline \hline$\#$ & Reactions & Reference & $\#$ & Reactions & References \\
\hline 1 & $\mathrm{O}_{2}+\mathrm{M} \rightleftharpoons 2 \mathrm{O}+\mathrm{M}$ & Ref. 27 & 2 & $\mathrm{~N}_{2}+\mathrm{M} \rightleftharpoons 2 \mathrm{~N}+\mathrm{M}$ & Ref. 27 \\
3 & $\mathrm{NO}+\mathrm{M} \rightleftharpoons \mathrm{N}+\mathrm{O}+\mathrm{M}$ & Ref. 27 & 4 & $\mathrm{NO}+\mathrm{O} \rightleftharpoons \mathrm{O}_{2}+\mathrm{N}$ & Ref. 27 \\
5 & $\mathrm{~N}_{2}+\mathrm{O} \rightleftharpoons \mathrm{NO}+\mathrm{N}$ & Ref. 27 & 6 & $\mathrm{~N}+\mathrm{O} \rightleftharpoons \mathrm{NO}^{+}+\mathrm{e}^{-}$ & Ref. 27 \\
7 & $\mathrm{O}+\mathrm{O} \rightleftharpoons \mathrm{O}_{2}^{+}+\mathrm{e}^{-}$ & Ref. 27 & 8 & $\mathrm{O}+\mathrm{O}_{2}^{+} \rightleftharpoons \mathrm{O}_{2}+\mathrm{O}^{+}$ & Ref. 27 \\
9 & $\mathrm{~N}_{2}+\mathrm{N}^{+} \rightleftharpoons \mathrm{N}+\mathrm{N}^{+}$ & Ref. 27 & 10 & $\mathrm{~N}+\mathrm{N} \rightleftharpoons \mathrm{N}_{2}^{+}+\mathrm{e}^{-}$ & Ref. 27 \\
11 & $\mathrm{O}_{2}+\mathrm{N}_{2} \rightleftharpoons \mathrm{NO}+\mathrm{NO}^{+}+\mathrm{e}^{-}$ & Ref. 27 & 12 & $\mathrm{NO}+\mathrm{M} \rightleftharpoons \mathrm{NO}^{+}+\mathrm{e}^{-}+\mathrm{M}$ & Ref. 27 \\
13 & $\mathrm{O}+\mathrm{NO}^{+} \rightleftharpoons \mathrm{NO}+\mathrm{O}^{+}$ & Ref. 27 & 14 & $\mathrm{~N}_{2}+\mathrm{O}^{+} \rightleftharpoons \mathrm{O}+\mathrm{N}_{2}^{+}$ & Ref. 27 \\
& & & & & \multicolumn{2}{c}{ Continued on next page }
\end{tabular}


Table 2 - continued from previous page

\begin{tabular}{|c|c|c|c|c|c|}
\hline$\#$ & Reactions & References & $\#$ & Reactions & References \\
\hline 15 & $\mathrm{~N}+\mathrm{NO}^{+} \rightleftharpoons \mathrm{NO}+\mathrm{O}^{+}$ & Ref. 27 & 16 & $\mathrm{O}_{2}+\mathrm{NO}^{+} \rightleftharpoons \mathrm{NO}+\mathrm{O}_{2}^{+}$ & Ref. 27 \\
\hline 17 & $\mathrm{O}+\mathrm{NO}^{+} \rightleftharpoons \mathrm{O}_{2}+\mathrm{N}^{+}$ & Ref. 27 & 18 & $\mathrm{~N}+\mathrm{e}^{-} \rightleftharpoons \mathrm{N}^{+}+\mathrm{e}^{-}+\mathrm{e}^{-}$ & Ref. 27 \\
\hline 19 & $\mathrm{O}+\mathrm{e}^{-} \rightleftharpoons \mathrm{O}^{+}+\mathrm{e}^{-}+\mathrm{e}^{-}$ & Ref. 27 & 20 & $\mathrm{CO}_{2}+\mathrm{M} \rightleftharpoons \mathrm{CO}+\mathrm{O}+\mathrm{M}$ & Ref. 28 \\
\hline 21 & $\mathrm{CO}+\mathrm{M} \rightleftharpoons \mathrm{C}+\mathrm{O}+\mathrm{M}$ & Ref. 28 & 22 & $\mathrm{C}_{2}+\mathrm{M} \rightleftharpoons 2 \mathrm{C}+\mathrm{M}$ & Ref. 29 \\
\hline 23 & $\mathrm{C}_{3}+\mathrm{M} \rightleftharpoons \mathrm{C}+\mathrm{C}_{2}+\mathrm{M}$ & Ref. 29 & 24 & $\mathrm{CN}+\mathrm{M} \rightleftharpoons \mathrm{C}+\mathrm{N}+\mathrm{M}$ & Ref. 29 \\
\hline 25 & $\mathrm{~N}_{2}+\mathrm{C} \rightleftharpoons \mathrm{CN}+\mathrm{N}$ & Ref. 29 & 26 & $\mathrm{CO}+\mathrm{N} \rightleftharpoons \mathrm{CN}+\mathrm{O}$ & Ref. 29 \\
\hline 27 & $\mathrm{CO}_{2}+\mathrm{N} \rightleftharpoons \mathrm{CN}+\mathrm{O}$ & Ref. 29 & 28 & $\mathrm{~N}_{2}+\mathrm{CO} \rightleftharpoons \mathrm{CN}+\mathrm{O}_{2}$ & Ref. 29 \\
\hline 29 & $\mathrm{CO}+\mathrm{NO} \rightleftharpoons \mathrm{CO}_{2}+\mathrm{N}$ & Ref. 29 & 30 & $\mathrm{CO}_{2}+\mathrm{O} \rightleftharpoons \mathrm{CO}+\mathrm{O}_{2}$ & Ref. 29 \\
\hline 31 & $\mathrm{CO}+\mathrm{CO} \rightleftharpoons \mathrm{CO}_{2}+\mathrm{C}$ & Ref. 29 & 32 & $\mathrm{CO}+\mathrm{O} \rightleftharpoons \mathrm{O}_{2}+\mathrm{C}$ & Ref. 29 \\
\hline 33 & $\mathrm{CO}+\mathrm{N} \rightleftharpoons \mathrm{C}+\mathrm{NO}$ & Ref. 29 & 34 & $\mathrm{CN}+\mathrm{O} \rightleftharpoons \mathrm{C}+\mathrm{NO}$ & Ref. 29 \\
\hline 35 & $\mathrm{CO}+\mathrm{CO} \rightleftharpoons \mathrm{C}_{2}+\mathrm{O}_{2}$ & Ref. 29 & 36 & $\mathrm{CO}+\mathrm{C} \rightleftharpoons \mathrm{C}_{2}+\mathrm{O}$ & Ref. 29 \\
\hline 37 & $\mathrm{C}_{2}+\mathrm{CO} \rightleftharpoons \mathrm{C}_{3}+\mathrm{O}$ & Ref. 29 & 38 & $\mathrm{C}_{3}+\mathrm{C} \rightleftharpoons \mathrm{C}_{2}+\mathrm{C}_{2}$ & Ref. 29 \\
\hline 39 & $\mathrm{CN}+\mathrm{H}_{2} \rightleftharpoons \mathrm{HCN}+\mathrm{H}$ & Ref. 30 & 40 & $\mathrm{H}_{2}+\mathrm{M} \rightleftharpoons 2 \mathrm{H}+\mathrm{M}$ & Ref. 31 \\
\hline 41 & $\mathrm{HCO}+\mathrm{M} \rightleftharpoons \mathrm{H}+\mathrm{CO}+\mathrm{M}$ & Ref. 31 & 42 & $\mathrm{HCO}+\mathrm{H} \rightleftharpoons \mathrm{CO}+\mathrm{H}_{2}$ & Ref. 31 \\
\hline 43 & $\mathrm{C}_{2} \mathrm{H}_{2}+\mathrm{M} \rightleftharpoons \mathrm{C}_{2} \mathrm{H}+\mathrm{H}+\mathrm{M}$ & Ref. 31 & 44 & $\mathrm{C}_{2} \mathrm{H}_{2}+\mathrm{H} \rightleftharpoons \mathrm{C}_{2} \mathrm{H}+\mathrm{H}_{2}$ & Ref. 31 \\
\hline 45 & $\mathrm{C}_{2} \mathrm{H}_{2}+\mathrm{O}_{2} \rightleftharpoons \mathrm{HCO}+\mathrm{HCO}$ & Ref. 31 & 46 & $\mathrm{C}_{2} \mathrm{H}+\mathrm{O}_{2} \rightleftharpoons \mathrm{HCO}+\mathrm{CO}$ & Ref. 31 \\
\hline 47 & $\mathrm{C}_{2} \mathrm{H}+\mathrm{O} \rightleftharpoons \mathrm{CH}+\mathrm{CO}$ & Ref. 31 & 48 & $\mathrm{CH}+\mathrm{O}_{2} \rightleftharpoons \mathrm{HCO}+\mathrm{O}$ & Ref. 31 \\
\hline 49 & $\mathrm{C}+\mathrm{O} \rightleftharpoons \mathrm{CO}^{+}+\mathrm{e}^{-}$ & Ref. 31 & 50 & $\mathrm{C}+\mathrm{e}^{-} \rightleftharpoons \mathrm{Cp}+\mathrm{e}^{-}+\mathrm{e}^{-}$ & Ref. 31 \\
\hline
\end{tabular}

\section{Olynick's model ${ }^{10}$}

The third model studied here was created for the pre-flight analysis of the Stardust re-entry vehicle, ${ }^{10}$ and uses 18 species and 22 reactions (9 dissociations). This model was build for efficiency, and therefore lacks important air species (the ionized diatomic molecules). The reaction rates used for the impact ionization reactions are also outdated, as are some of the carbon chemistry rates. The other drawback is that the model lacks almost any hydrocarbon chemistry, with only two equations involving the element H. Finally, most of the rates involving carbon species are taken from a model built and validated for the atmospheric conditions of Mars, ${ }^{23}$ which are not the same temperature and pressure ranges as carbon-phenolic-in-air surface ablation. The reactions of this model are listed in Table 3, and the species are:

$$
\mathrm{C}, \mathrm{O}, \mathrm{N}, \mathrm{H}, \mathrm{CO}, \mathrm{C}_{2}, \mathrm{~N}_{2}, \mathrm{CN}, \mathrm{NO}, \mathrm{O}_{2}, \mathrm{H}_{2}, \mathrm{CO}_{2}, \mathrm{C}_{3}, \mathrm{HCN}, \mathrm{C}^{+}, \mathrm{O}^{+}, \mathrm{N}^{+}, \mathrm{e}^{-}
$$

Table 3: Reactions for Olynicks's 18 species chemistry model

\begin{tabular}{|c|c|c|c|c|c|}
\hline \# & Reactions & Reference & \# & Reactions & References \\
\hline 1 & $\mathrm{CO}_{2}+\mathrm{M} \rightleftharpoons \mathrm{CO}+\mathrm{O}+\mathrm{M}$ & Ref. 23 & 2 & $\mathrm{CO}+\mathrm{M} \rightleftharpoons \mathrm{C}+\mathrm{O}+\mathrm{M}$ & Ref. 23 \\
\hline 3 & $\mathrm{~N}_{2}+\mathrm{M} \rightleftharpoons 2 \mathrm{~N}+\mathrm{M}$ & Ref. 23 & 4 & $\mathrm{O}_{2}+\mathrm{N}_{2} \rightleftharpoons \mathrm{NO}+\mathrm{NO}^{+}+\mathrm{e}^{-}$ & Ref. 23 \\
\hline 5 & $\mathrm{NO}+\mathrm{M} \rightleftharpoons \mathrm{N}+\mathrm{O}+\mathrm{M}$ & Ref. 23 & 6 & $\mathrm{C}_{2}+\mathrm{M} \rightleftharpoons 2 \mathrm{C}+\mathrm{M}$ & Ref. 23 \\
\hline 7 & $\mathrm{C}_{3}+\mathrm{M} \rightleftharpoons \mathrm{C}+\mathrm{C}_{2}+\mathrm{M}$ & Ref. 32 & 8 & $\mathrm{CN}+\mathrm{M} \rightleftharpoons \mathrm{C}+\mathrm{N}+\mathrm{M}$ & Ref. 23 \\
\hline 9 & $\mathrm{H}_{2}+\mathrm{M} \rightleftharpoons 2 \mathrm{H}+\mathrm{M}$ & Ref. 33 & 10 & $\mathrm{NO}+\mathrm{O} \rightleftharpoons \mathrm{O}_{2}+\mathrm{N}$ & Ref. 23 \\
\hline 11 & $\mathrm{~N}_{2}+\mathrm{O} \rightleftharpoons \mathrm{NO}+\mathrm{N}$ & Ref. 23 & 12 & $\mathrm{CO}+\mathrm{O} \rightleftharpoons \mathrm{O}_{2}+\mathrm{C}$ & Ref. 23 \\
\hline 13 & $\mathrm{CO}_{2}+\mathrm{O} \rightleftharpoons \mathrm{CO}+\mathrm{O}_{2}$ & Ref. 23 & 14 & $\mathrm{CO}+\mathrm{C} \rightleftharpoons \mathrm{C}_{2}+\mathrm{O}$ & Ref. 23 \\
\hline 15 & $\mathrm{CO}+\mathrm{N} \rightleftharpoons \mathrm{CN}+\mathrm{O}$ & Ref. 23 & 16 & $\mathrm{~N}_{2}+\mathrm{C} \rightleftharpoons \mathrm{CN}+\mathrm{N}$ & Ref. 23 \\
\hline 17 & $\mathrm{CN}+\mathrm{O} \rightleftharpoons \mathrm{C}+\mathrm{NO}$ & Ref. 23 & 18 & $\mathrm{CN}+\mathrm{C} \rightleftharpoons \mathrm{C}_{2}+\mathrm{N}$ & Ref. 23 \\
\hline 19 & $\mathrm{HCN}+\mathrm{H} \rightleftharpoons \mathrm{CN}+\mathrm{H}_{2}$ & Ref. 30 & 20 & $\mathrm{C}+\mathrm{e}^{-} \rightleftharpoons \mathrm{Cp}+\mathrm{e}^{-}+\mathrm{e}^{-}$ & Ref. 34 \\
\hline 21 & $\mathrm{~N}+\mathrm{e}^{-} \rightleftharpoons \mathrm{N}^{+}+\mathrm{e}^{-}+\mathrm{e}^{-}$ & Ref. 34 & 22 & $\mathrm{O}+\mathrm{e}^{-} \rightleftharpoons \mathrm{O}^{+}+\mathrm{e}^{-}+\mathrm{e}^{-}$ & Ref. 34 \\
\hline
\end{tabular}

\section{Model comparison}

In order to evaluate the three models, a CFD test case is run using the forebody of the Stardust return capsule, 48 seconds into re-entry (a few seconds before peak heating). ${ }^{35}$ This test case is chosen because uncoupled ablation calculations show a high blowing rate and a diverse representation of blowing species, as 
detailed in Ref. 11. The flow and surface parameters are presented in Tables 4 and 5, respectively, and the geometry and mesh in Fig. 1. To simplify the simulation, the flow is considered to be axisymmetric, and the wall temperature and blowing rates are applied uniformly on the surface. Gibb's Free Energy is used to calculate the equilibrium constants needed for the backward reaction rates, and the transport properties are calculated from Lennard-Jones potentials, using CHEMKIN, ${ }^{36}$ to produce individual species temperature dependant viscosity curve fits.

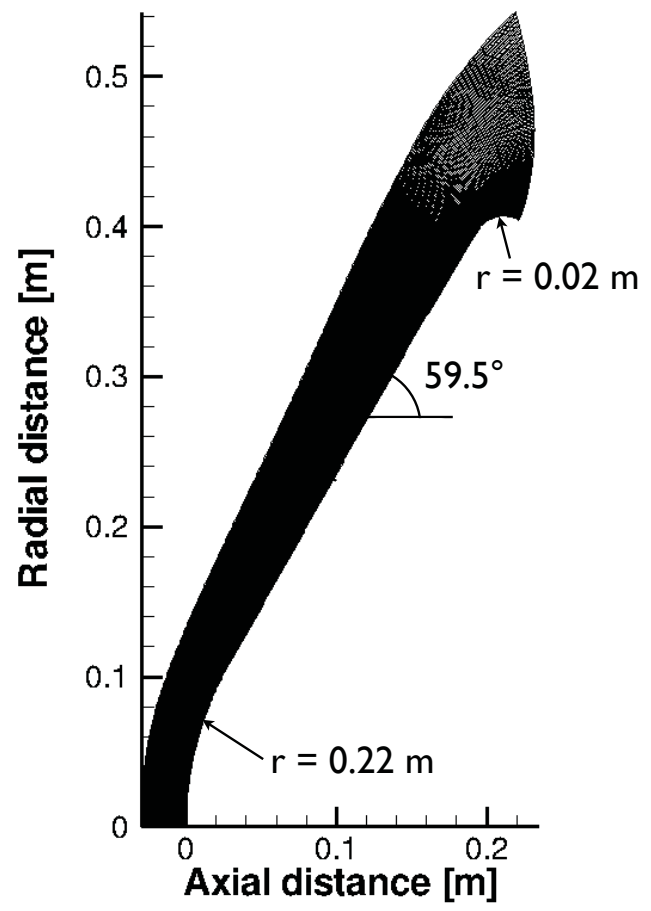

(a) Geometry and overall mesh

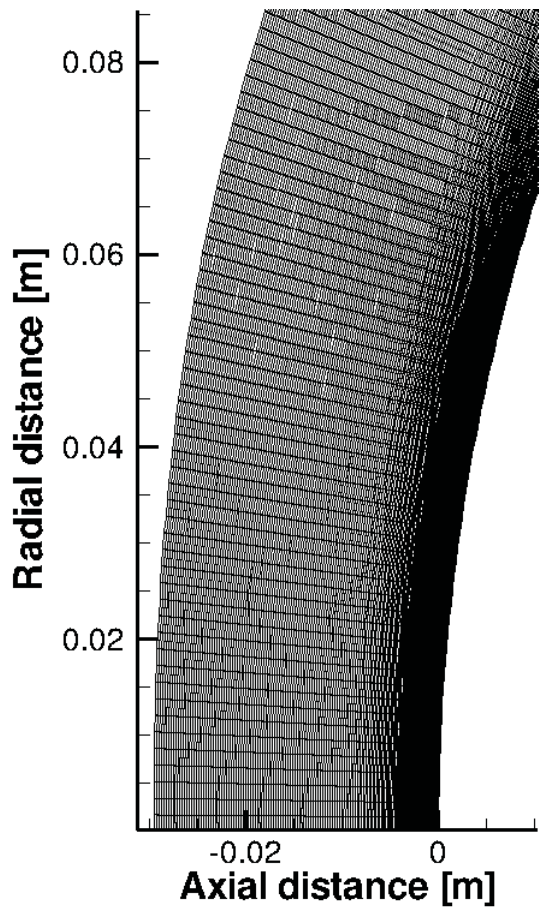

(b) Stagnation region mesh

Figure 1. Geometry and mesh of the Stardust re-entry capsule, used for the chemistry model comparison

Table 4. Free stream condition for the 48 s trajectory point of the Stardust re-entry

\begin{tabular}{ccccc}
\hline \hline $\begin{array}{c}U_{\infty} \\
{[\mathrm{km} / \mathrm{s}]}\end{array}$ & $\begin{array}{c}T_{\infty} \\
{[\mathrm{K}]}\end{array}$ & $\begin{array}{c}\rho_{\infty} \\
{\left[\mathrm{kg} / \mathrm{m}^{3}\right]}\end{array}$ & $Y_{N_{2}}$ & $Y_{O_{2}}$ \\
\hline 11.414 & 230.8 & $1.4099 \times 10^{-4}$ & 0.7635 & 0.2365 \\
\hline \hline
\end{tabular}

Table 5. Wall condition at stagnation for for the 48s trajectory point of the Stardust re-entry

\begin{tabular}{cccccccc}
\hline \hline $\begin{array}{c}T_{w} \\
{[\mathrm{~K}]}\end{array}$ & $\begin{array}{c}\dot{m}_{w} \\
{\left[\mathrm{~kg} / \mathrm{m}^{2} / \mathrm{s}\right]}\end{array}$ & $Y_{N_{2}}$ & $Y_{C O}$ & $Y_{C_{2} H}$ & $Y_{C_{3}}$ & $Y_{C N}$ & $Y_{H_{2}}$ \\
\hline 3343.2 & 0.07277 & 0.4670 & 0.3200 & 0.0752 & 0.0489 & 0.0467 & 0.0419 \\
\hline \hline
\end{tabular}

\section{Model comparisons and validations without ablating species}

As an initial comparison, Fig. 2 presents a comparison between the two de facto models used in CFD, the 5 and 11 species models devised by Park, as well as the three ablation chemistry models studied here. 
Except for the 5 species model, which is not expected to be valid at these conditions, all other models are in good agreement, although noticeable differences are present in the boundary layer, as well as in the shock structure. The 5 species model and the 11 species model labeled as Curve fits uses Park's equilibrium constants curve fits for the equilibrium constants. Figure 3 shows that the model are in good agreement when heat fluxes are compared; even the 5 species model gives accurate results.

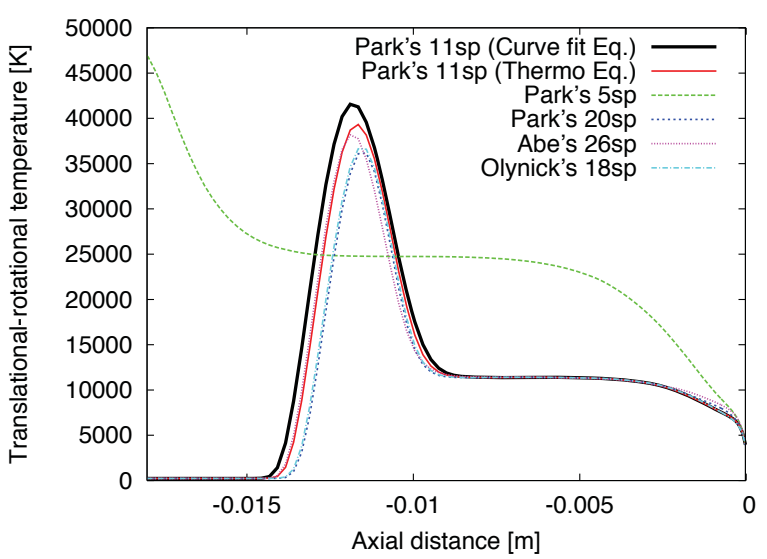

(a) Translational-rotational temperature

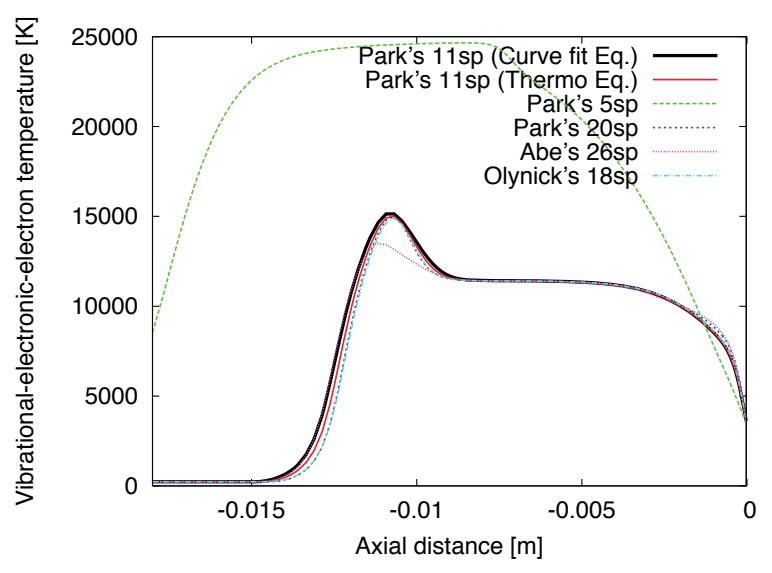

(c) Vibrational-electronic-electron temperature

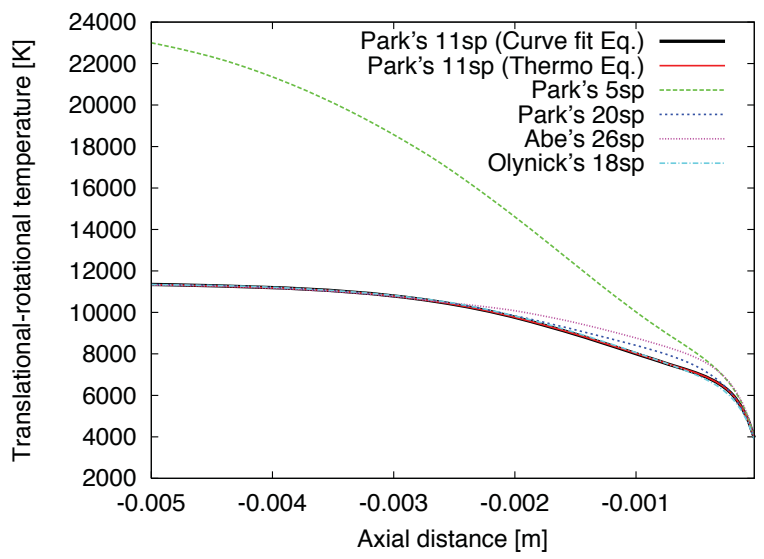

(b) Translational-rotational temperature

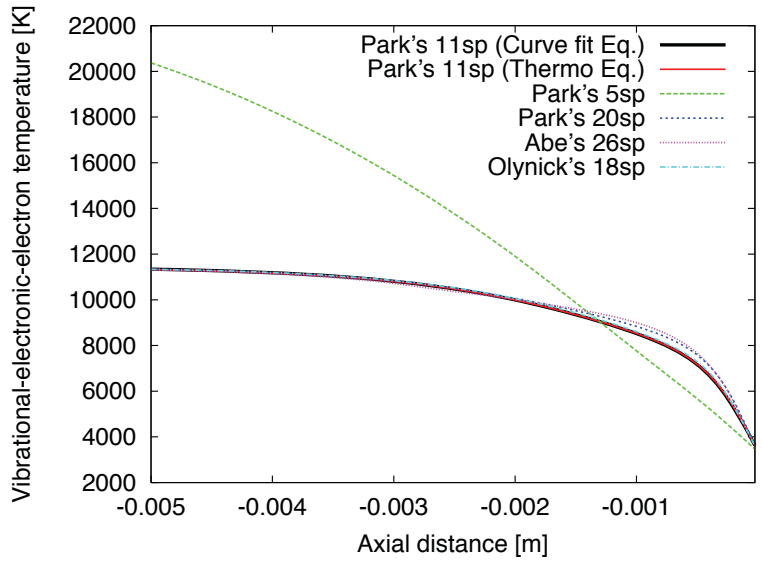

(d) Vibrational-electronic-electron temperature

Figure 2. Stagnation line temperatures for different chemistry models

\section{Park's 20 species model}

Figure 4a) presents the stagnation line temperatures using the 20 species model. As expected, the flow is strongly nonequilibrium. Figure 4b) shows the air species number density on the stagnation line, as it goes through the shock. This particular test case has the flow highly ionized, which indicates that $\mathrm{O}_{2}^{+}$should be present to better evaluate the shock. However, this species becomes insignificant post shock. Figure 4c) shows the non-air species on the stagnation line, as 4d) shows the same species in the region near the wall. It can be seen that all molecules are rapidly dissociated, and that the atoms are ionized as they enter the post-shock region. It is also interesting to note that the $\mathrm{C}_{2}$ molecule is present in a very limited amount, even if it is very important as it provides the main reaction path to decompose $\mathrm{C}_{3}$ into $\mathrm{C}$. It is, however, surprising to see that $C_{3}$ remains at such high values; the fact that this molecule is not allowed to dissociate is the main reason why. The only path available to reduce $\mathrm{C}_{3}$ is by exchange reactions with atomic species, which are not efficient at these conditions. One interesting phenomenon to observe is the rapid ionization of $\mathrm{C}$ and $\mathrm{H}$. These two species are not blown from the surface, and are therefore created by the dissociation of the larger molecules. As they are created, they immediately start to become ionized before being convected 


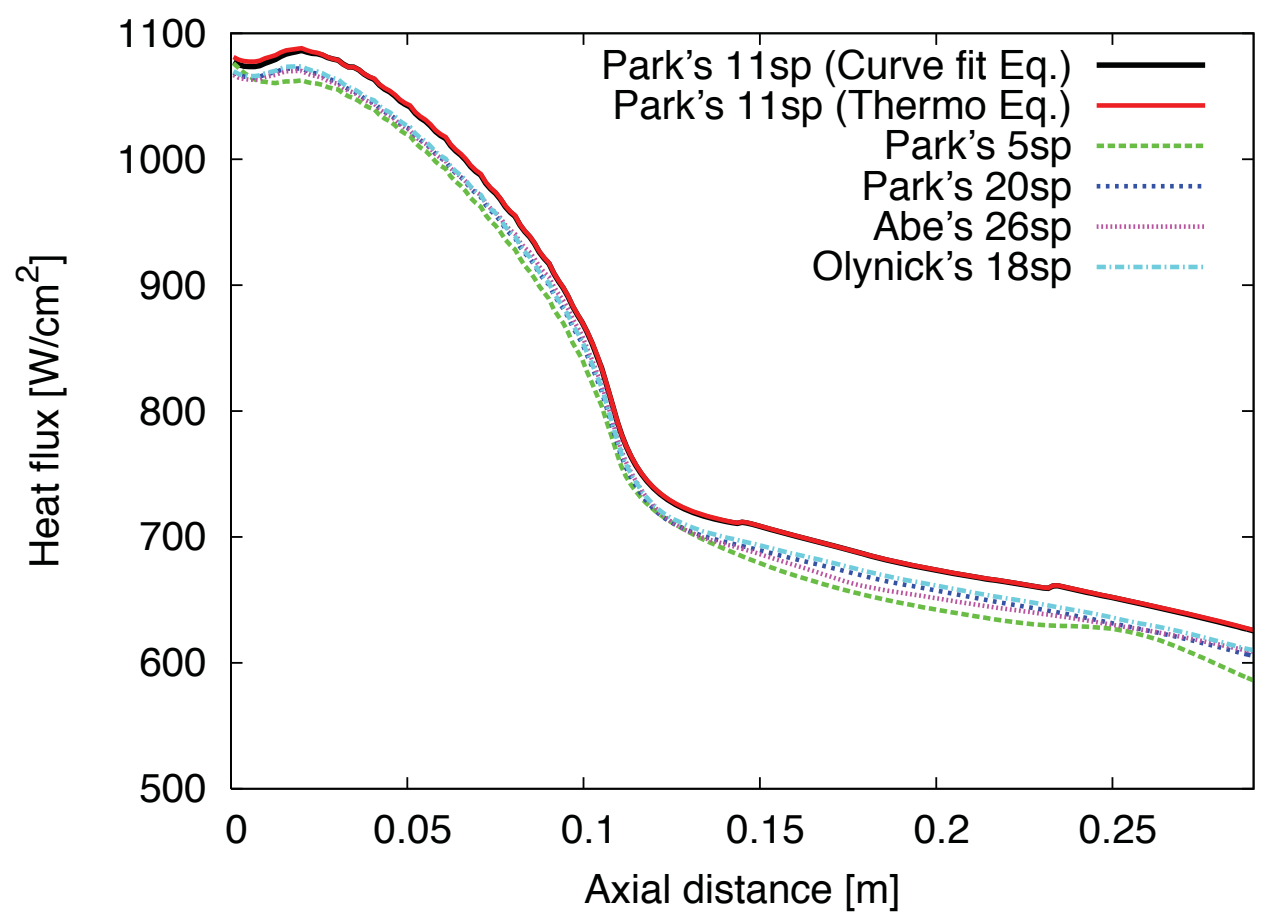

Figure 3. Surface heat flux for different chemistry models

away.

\section{Abe's 26 species model}

The results for the 26 species model are presented in Fig. 5. Compared to the results obtained with Park's model, the boundary layer composition of this model shows the expected behavior, as the larger molecules are quickly destroyed. This behavior is due to the inclusion of more dissociation reactions (12 instead of 5). The rapid dissociation of both $\mathrm{C}_{3}$ and $\mathrm{C}_{2} \mathrm{H}$, two molecules injected at the surface, is quite evident in Fig. 5c). It is also interesting to note that $\mathrm{C}_{2} \mathrm{H}_{2}$ and $\mathrm{CO}_{2}$ are immediately created at the surface, but rapidly disappear as they move away from the surface. Figure 5f) also shows that excluding $\mathrm{CO}^{+}$might not be a bad assumption, in this particular case, as the number density never reaches a significant value, even though $\mathrm{C}$ and $\mathrm{O}$ (the species needed to create $\mathrm{CO}^{+}$) are present in great quantity. The same conclusion cannot be drawn for $\mathrm{HCO}$ as this molecule could provide important reaction paths to other molecules. As for HCN, even if this particular test-case does not include it as a blown species, equilibrium composition study shows that it can be an important product of carbon-phenolic decomposition. ${ }^{11}$ The same graph also shows that $\mathrm{CH}$ is an important molecule to account for, as it is rapidly created and becomes stable in the boundary layer. It is to be noted that $\mathrm{CH}$ dissociation is not included in the nodel, and that could explain why the species is not decomposed immediately.

\section{Olynick's 18 species model}

In order to be able to run this particular model in LeMANS, the electron impact ionization rates are changed to the ones calculated and used by Park. ${ }^{22}$ The results along the stagnation streamline in the post shock region and the boundary layer are presented in Fig. 6. Even though dissociation reactions are present, the large molecules are not immediately reduced, similar to Park's model. $\mathrm{C}_{2}$ because of the inclusion of its formation reaction appears in greater density, but not as much as with Abe's model. As with the other models, the atomic species are dominating near the wall. HCN is not present on the plot, as the only chemical reaction that involves it is more prone at reducing it than creating it, at these conditions. It is to be noted that $\mathrm{C}_{2} \mathrm{H}$ appears in unusually high quantity; the reason is that this molecule is not included in the 


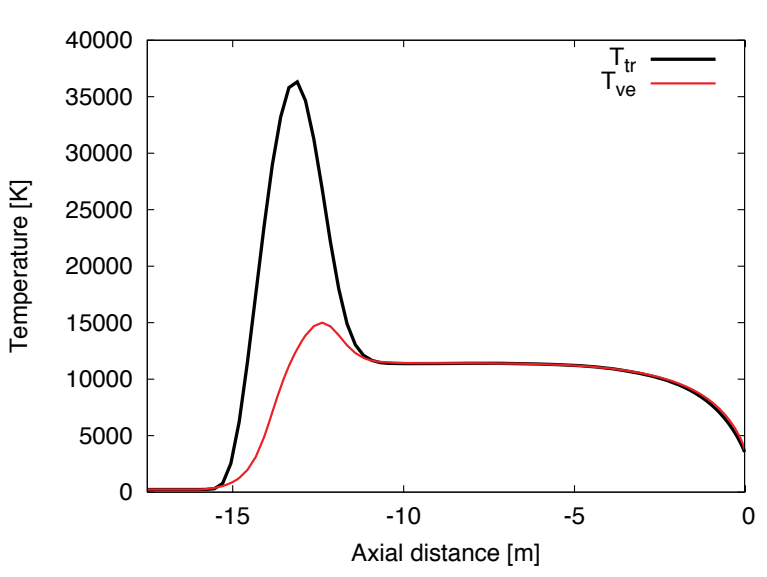

(a) Temperatures

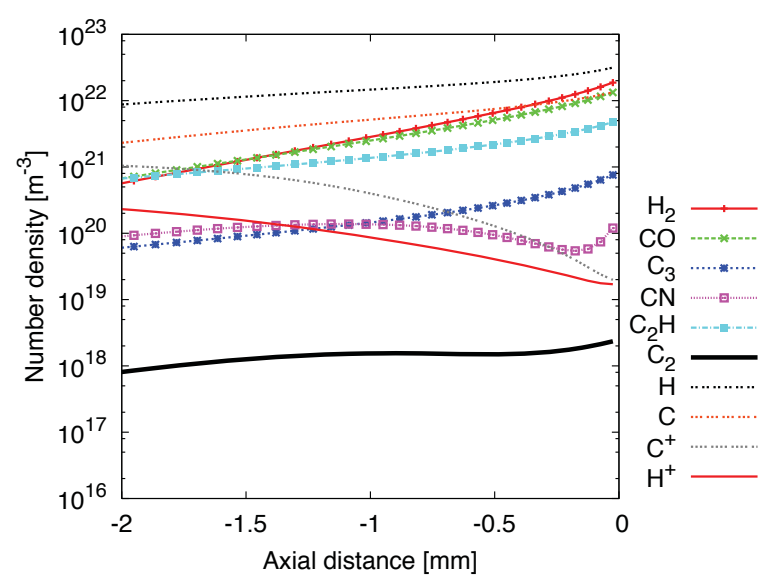

(c) Non-air species, near the wall

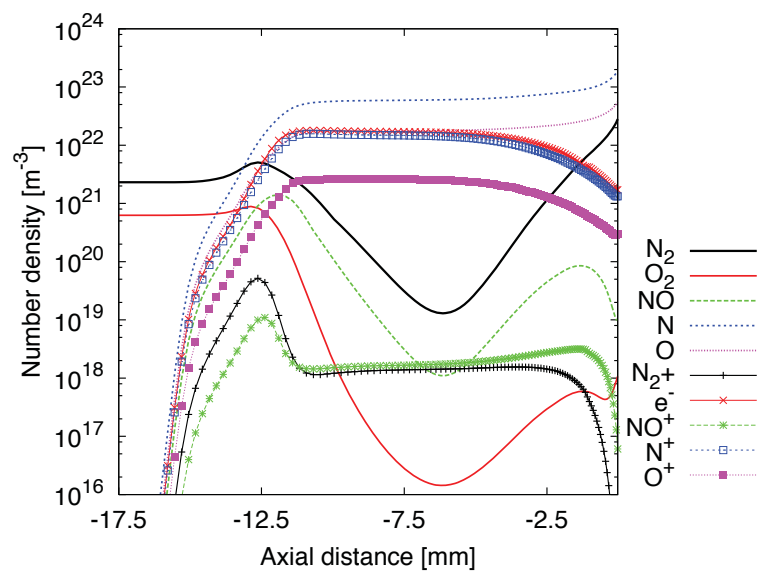

(b) Air species

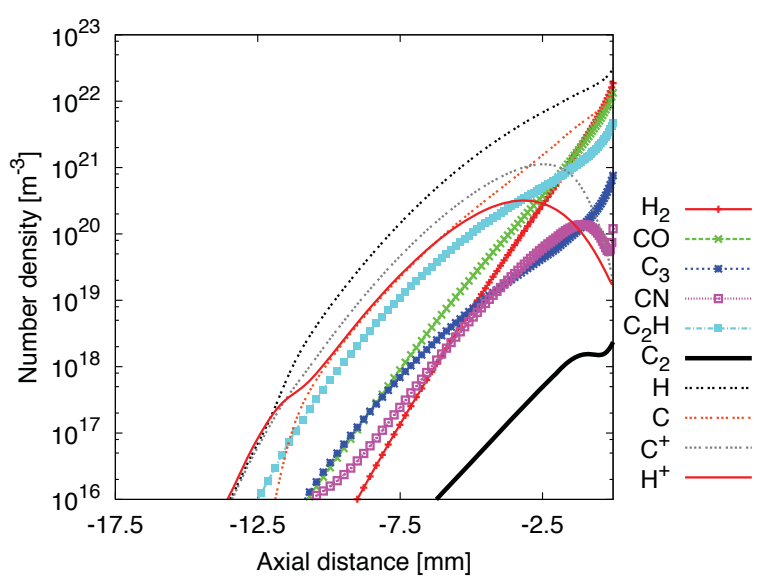

(d) Non-air species

Figure 4. Stagnation line results for the Stardust return capsule at 48 s into re-entry, using Park's 20 species chemistry model 


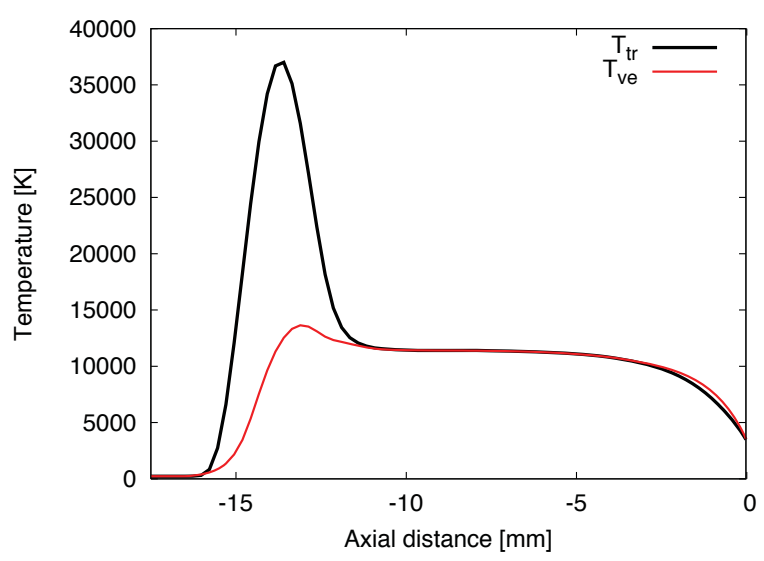

(a) Temperatures

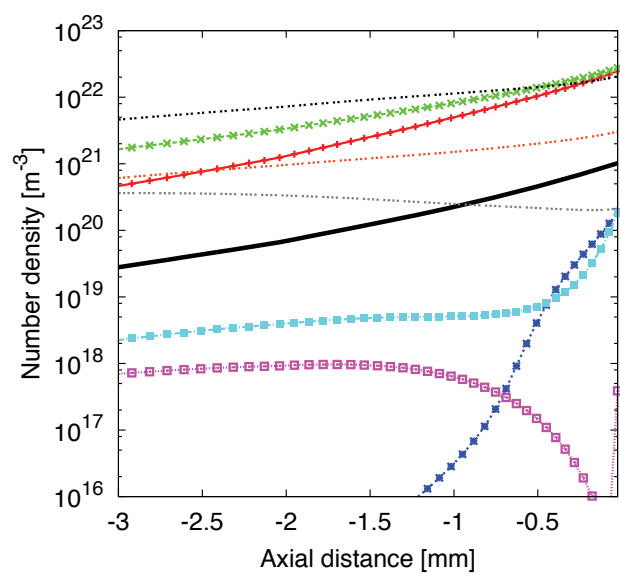

(c) Non-air species, near the wall

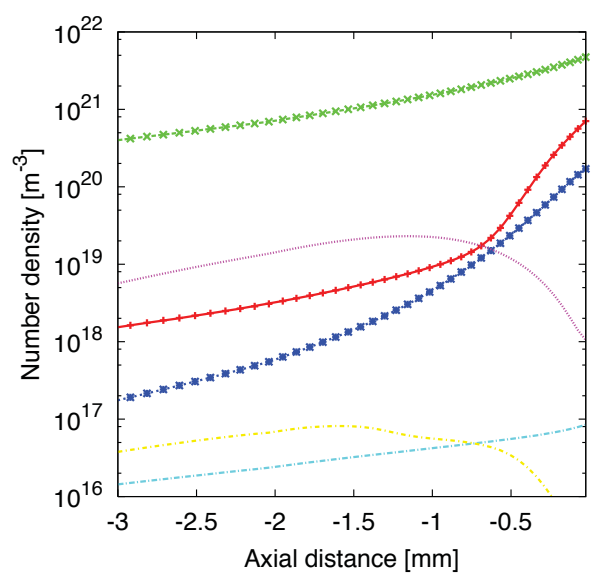

(e) Non-air species not in the $20 \mathrm{sp}$. model, near the wall

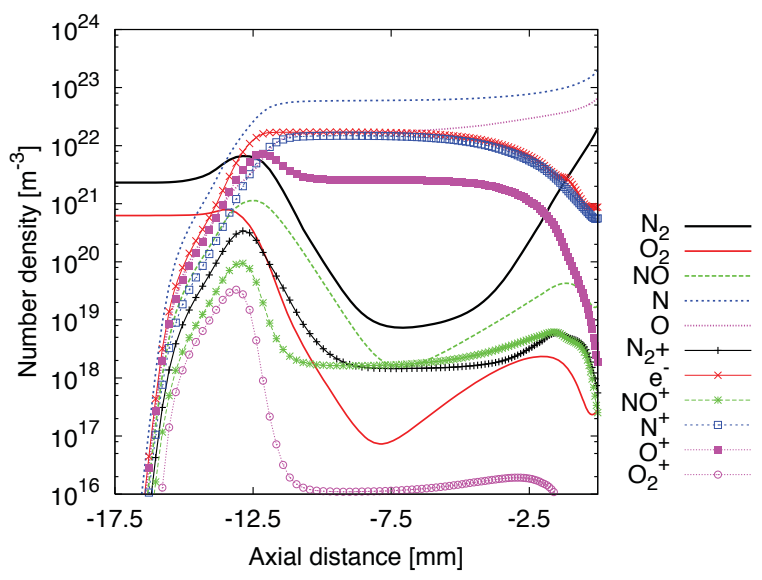

(b) Air species

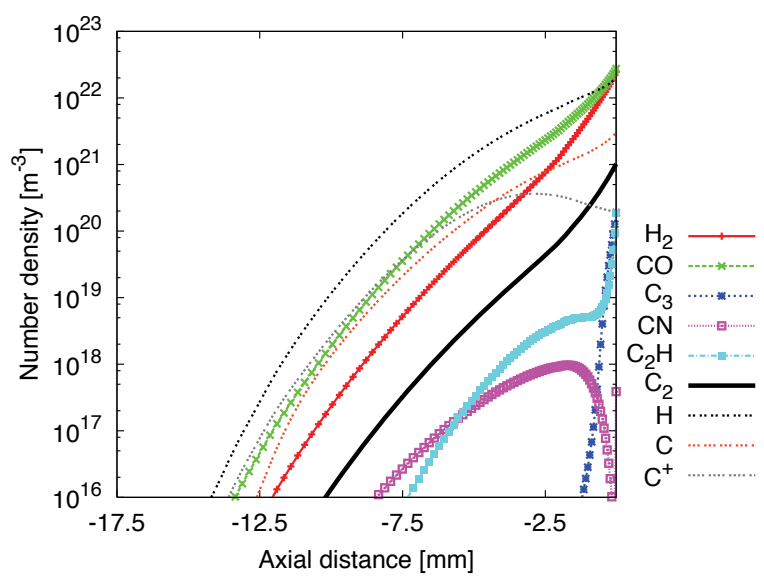

(d) Non-air species

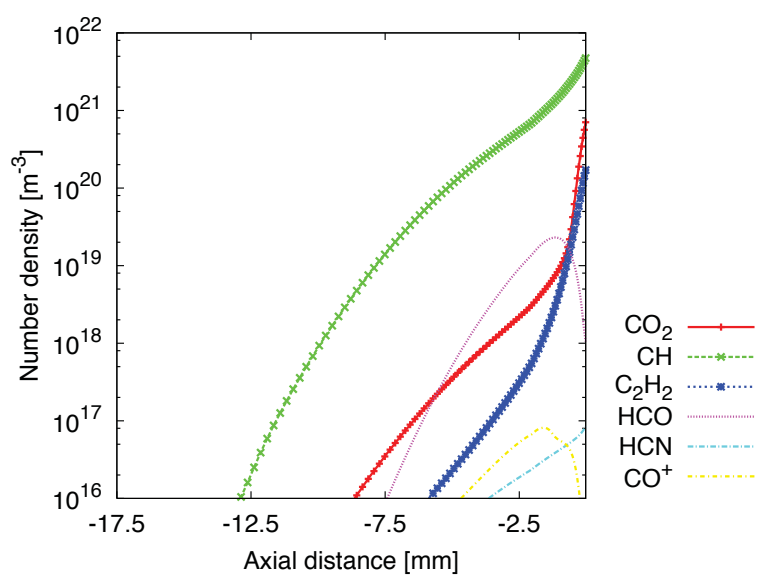

(f) Non-air species not in the 20 sp. model

Figure 5. Stagnation line results for the Stardust return capsule at 48s into re-entry, using Abe's 26 species chemistry model 
chemistry model, and therefore is non-reacting. Finally, we also point out that, as is the case with Park's model, this one also does not include $\mathrm{CH}$, which, as shown in the Abe model, can be an important species.

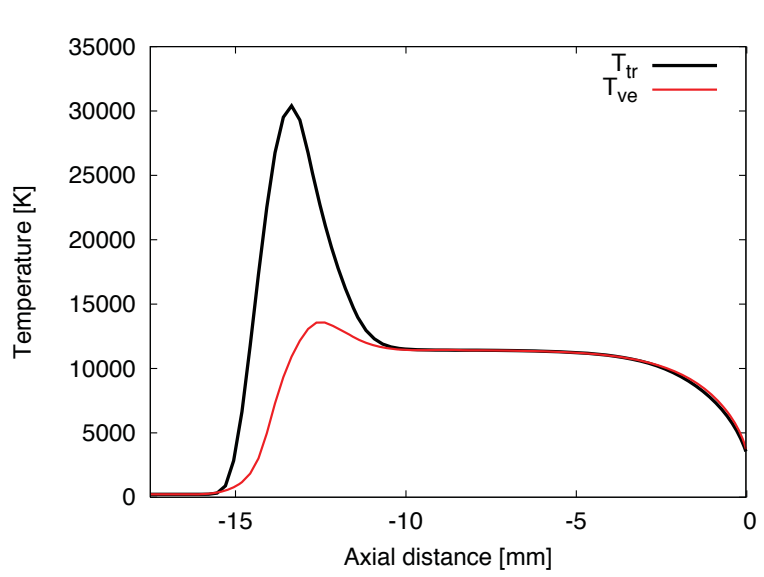

(a) Temperatures

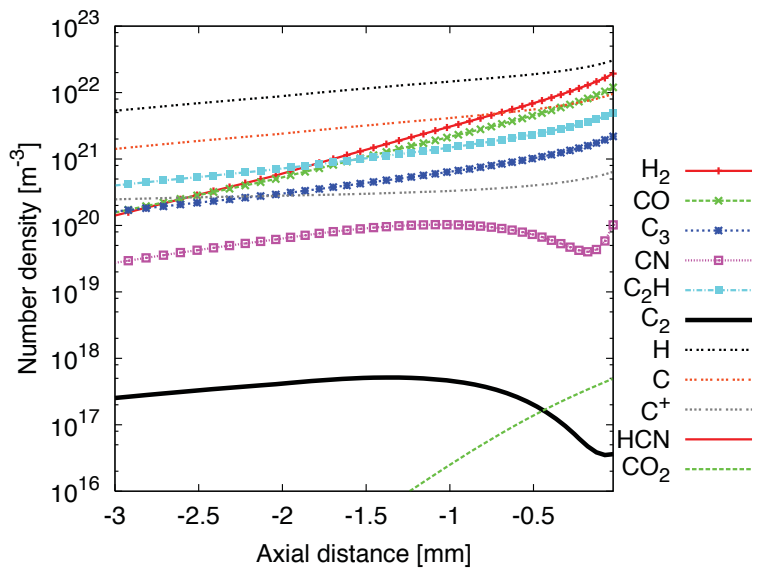

(c) Non-air species, near the wall

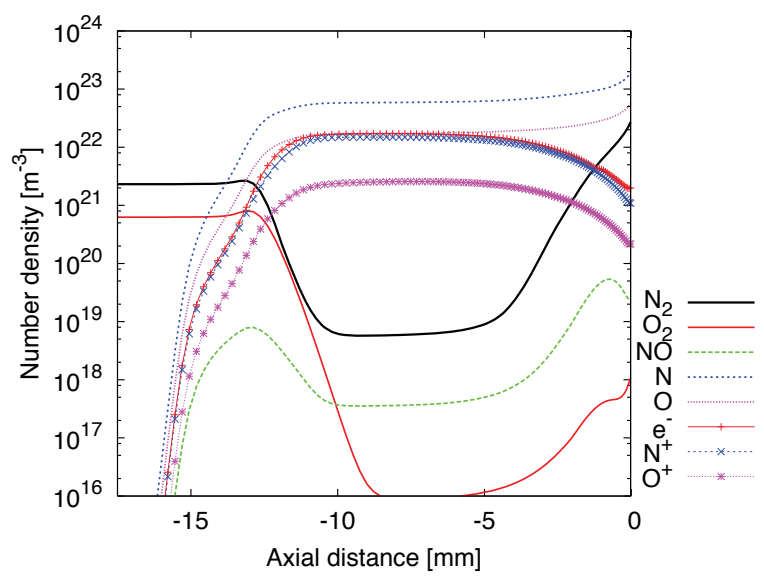

(b) Air species

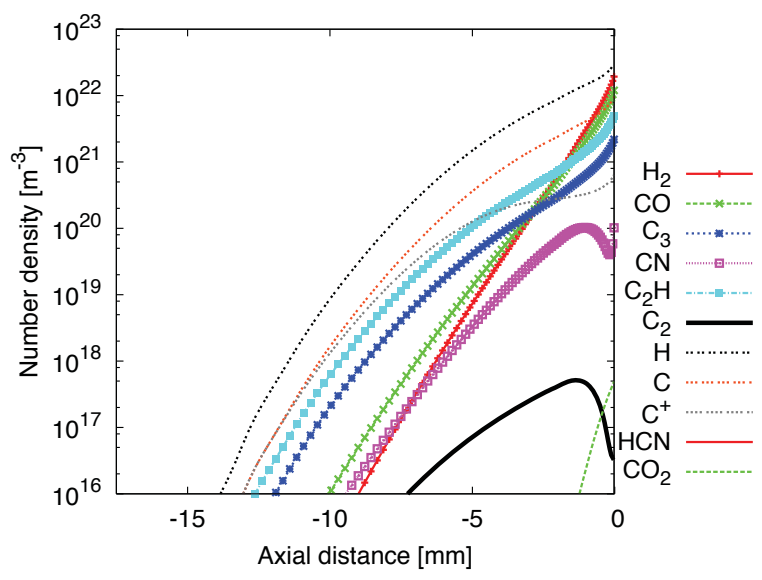

(d) Non-air species

Figure 6. Stagnation line results for the Stardust return capsule at 48 s into re-entry, using Olynick's 18 species chemistry model

\section{Heat flux}

An important aspect of the analysis is the evaluation and comparison of the heat fluxes. As was shown for the same geometry, ${ }^{10}$ ablation reduces significantly the overall heat flux to the surface. The total convective heat flux, which includes conduction and mass diffusion, is presented in Fig. 7a). The discrepancy between models is quite significant, especially between the Abe model and the other two. Figures 7b) to d) show the individual components of the convective heat fluxes. It is not surprising to see that the 18 and 20 species models are nearly identical as they share most of their sources for the kinetic rates. It is interesting to see that, even though the boundary layer composition is very different, which is expected to impact the mass diffusion heat transfer, it is mainly the translation-rotation conductive heat fluxes that are different. In this particular case, it would be interesting to fully decouple all temperatures to properly evaluate the contribution of each mode.

The radiative heat fluxes are also evaluated. Certain species present in the boundary layer are strong radiative emitters, and are expected to significantly contribute to the overall radiative emission to the surface. The calculation is performed along the stagnation line of a converged flow field solution, using the non-equilibrium radiation code NEQAIR (version 99d). ${ }^{37}$ Apart from the usual air species, the emission 


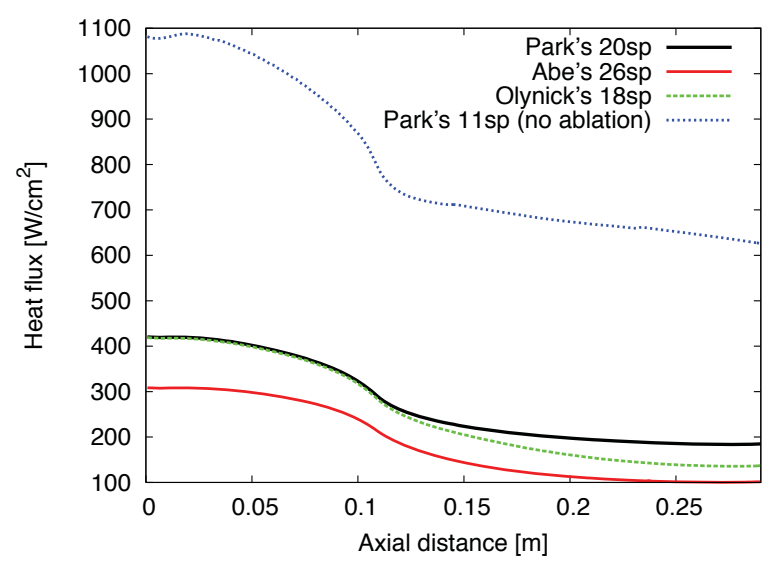

(a) Comparison of the total heat flux for the thre ablation models; the non-ablating value is plotted as a reference

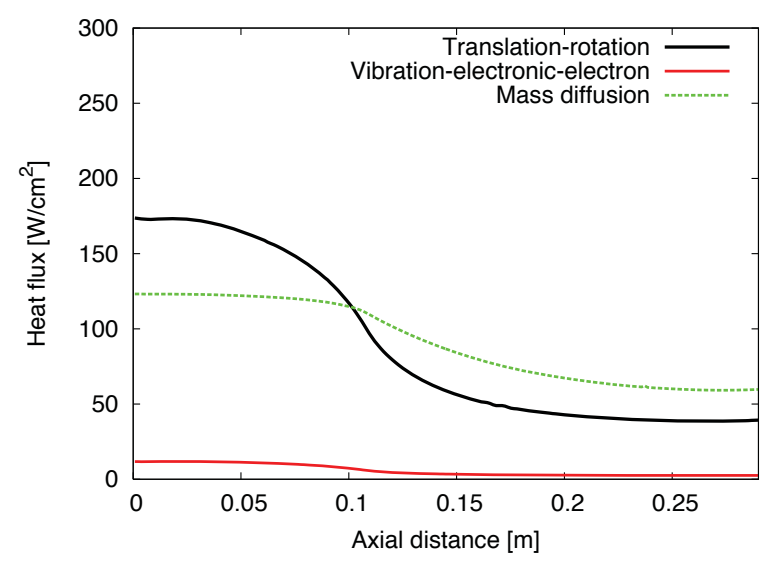

(c) Separated components of the heat fluxes for Abe's model

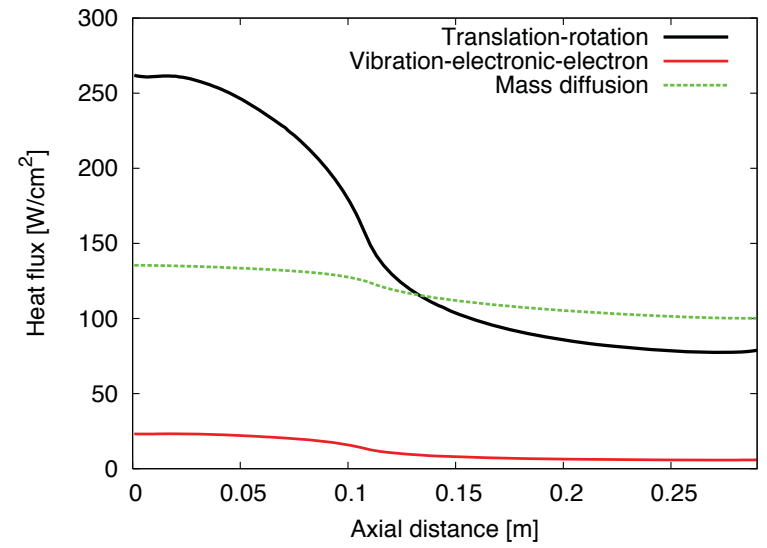

(b) Separated components of the heat fluxes for Park's model

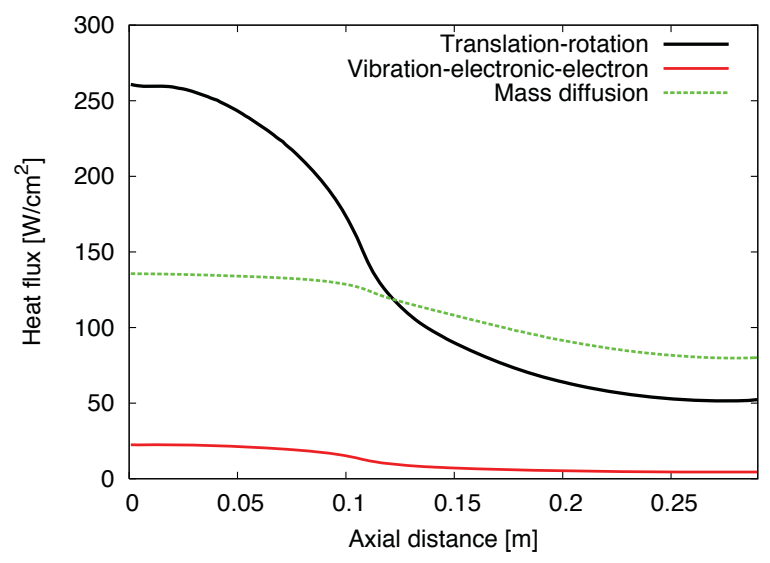

(d) Separated components of the heat fluxes for Olynick's model

Figure 7. Comparison of the heat fluxes for the different chemistry models 
from the species listed in Table 6 is included. The heat flux is calculated by considering the emission at wavelengths between 200 and $1000 \mathrm{~nm}$.

The results are summarized in Table 7 . The radiative flux, when the hydro-carbon species are included, is significantly increased for the 18 and 20 species models. However, because the convective heat fluxes are greatly reduced, radiation is now contributing more to the total heat flux for all three models. It is also important to note that the differences in radiative heat flux are quite pronounced, especially when comparing the 26 species models and the other two. This behavior is expected as the 18 and 20 species model are very similar. Considering this important increase in radiative heat flux, further study of the reaction mechanisms is required.

Table 6. Emission mechanisms considered for the radiative heat flux, excluding the air species

\begin{tabular}{cc}
\hline \hline Species & Mechanism \\
\hline $\mathrm{CN}$ & Violet $\left(\mathrm{B}^{1} \Sigma-\mathrm{X}^{1} \Sigma\right)$ \\
$\mathrm{CO}$ & $4+\left(\mathrm{A}^{1} \Pi-\mathrm{X}^{1} \Sigma\right)$ \\
$\mathrm{C}_{2}$ & Swan $\left(\mathrm{d}^{3} \Pi-\mathrm{a}^{4} \Pi\right)$ \\
$\mathrm{H}_{2}$ & Lyman $\left(\mathrm{B}^{1} \Sigma-\mathrm{X}^{1} \Sigma\right)$ \\
$\mathrm{H}_{2}$ & Werner $\left(\mathrm{C}^{1} \Pi-\mathrm{X}^{1} \Sigma\right)$ \\
$\mathrm{H}_{2}$ & $\mathrm{~B} \Sigma-\mathrm{X}^{1} \Sigma$ \\
\hline
\end{tabular}

Table 7. Radiative heat flux for the different chemistry model at wavelengths between $200-1000 \mathrm{~nm}$

\begin{tabular}{|c|c|c|c|c|c|c|}
\hline & \multicolumn{3}{|c|}{ No-ablation } & \multicolumn{3}{|c|}{ Ablation } \\
\hline & Convective & Radiative & $\%$ of total flux & Convective & Radiative & $\%$ of total flux \\
\hline 20 species & $1070 \mathrm{~W} / \mathrm{cm}^{2}$ & $11.9 \mathrm{~W} / \mathrm{cm}^{2}$ & $1.10 \%$ & $420 \mathrm{~W} / \mathrm{cm}^{2}$ & $61.7 \mathrm{~W} / \mathrm{cm}^{2}$ & $12.8 \%$ \\
\hline 26 species & $1070 \mathrm{~W} / \mathrm{cm}^{2}$ & $18.4 \mathrm{~W} / \mathrm{cm}^{2}$ & $1.69 \%$ & $309 \mathrm{~W} / \mathrm{cm}^{2}$ & $21.9 \mathrm{~W} / \mathrm{cm}^{2}$ & $6.25 \%$ \\
\hline 18 species & $1070 \mathrm{~W} / \mathrm{cm}^{2}$ & $12.7 \mathrm{~W} / \mathrm{cm}^{2}$ & $1.17 \%$ & $420 \mathrm{~W} / \mathrm{cm}^{2}$ & $52.6 \mathrm{~W} / \mathrm{cm}^{2}$ & $11.1 \%$ \\
\hline
\end{tabular}

\section{New chemistry model}

The previous results show that there is a need to develop an exhaustive, validated and properly reduced chemistry model for ablating carbon phenolic in air. Steps in this direction have already been taken, with the recent publication of such a model. ${ }^{11}$ The model is constructed by carefully selecting the species important to carbon-phenolic ablation in air, finding all the associated reactions, and then reducing the model by using sensitivity analysis. The set of reactions and species is then validated by comparing to experimental data and to a complete model using flight-like conditions. An example of the latter is presented in Fig. 8; the species concentrations overlap, and no difference is observable for the important species. The reduced model is composed of the following 37 species:

$$
\begin{gathered}
\mathrm{C}_{2} \mathrm{H}, \mathrm{C}_{2} \mathrm{H}_{2}, \mathrm{C}_{3}, \mathrm{CH}_{3}, \mathrm{CH}_{4}, \mathrm{CO}, \mathrm{CO}_{2}, \mathrm{H}, \mathrm{H}_{2}, \mathrm{H}_{2} \mathrm{O}, \mathrm{HCN}, \mathrm{N}, \mathrm{N}_{2}, \mathrm{NO}, \mathrm{O}, \mathrm{O}_{2}, \mathrm{OH}, \\
\mathrm{N}_{2}^{+}, \mathrm{N}^{+}, \mathrm{O}^{+}, \mathrm{NO}^{+}, \mathrm{O}_{2}^{+}, \mathrm{CO}^{+}, \mathrm{C}^{+}, \mathrm{H}^{+} \mathrm{e}^{-}, \\
\mathrm{CH}, \mathrm{CH}_{2}, \mathrm{C}, \mathrm{C}_{2}, \mathrm{NCO}, \mathrm{NH}, \mathrm{HNO}, \mathrm{HCO}, \mathrm{H}_{2} \mathrm{O}_{2}, \mathrm{HO}_{2}, \mathrm{CN}
\end{gathered}
$$

and uses the 152 reactions listed in Ref. 11.

This reduced model, however accurate, remains too large to use in a CFD code. In order to further simplify it, a CFD sensitivity analysis needs to be performed. For instance, the DAKOTA sensitivity analysis and uncertainty quantification software ${ }^{38}$ could provide the appropriate framework to analyze and quantify the impact of each reaction and species on the flow field. It is expected that a model comprising 32 species and 120 reactions could be obtained. 


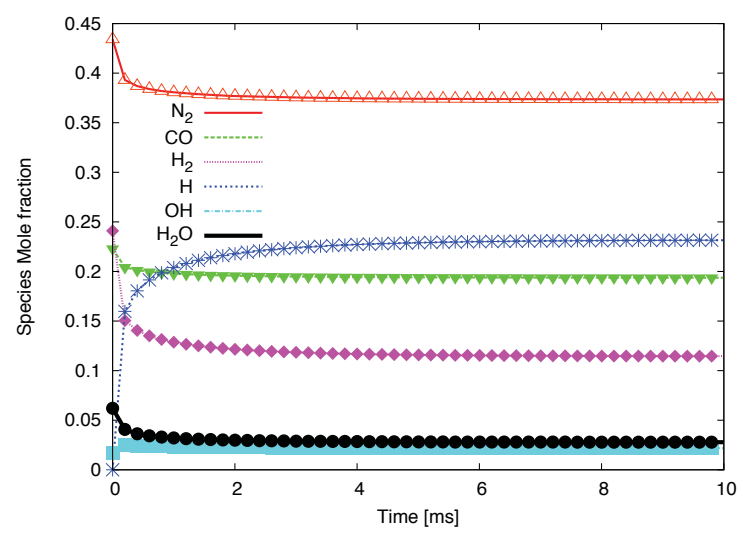

(a) High concentration species

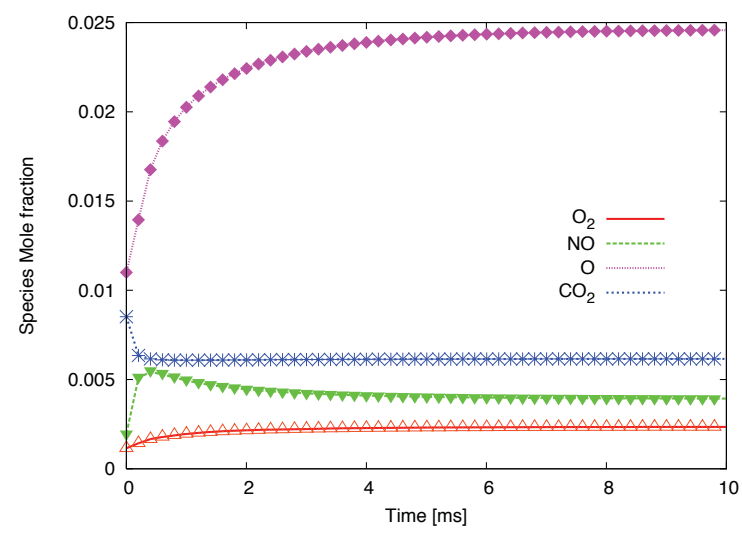

(b) Mid concentration species

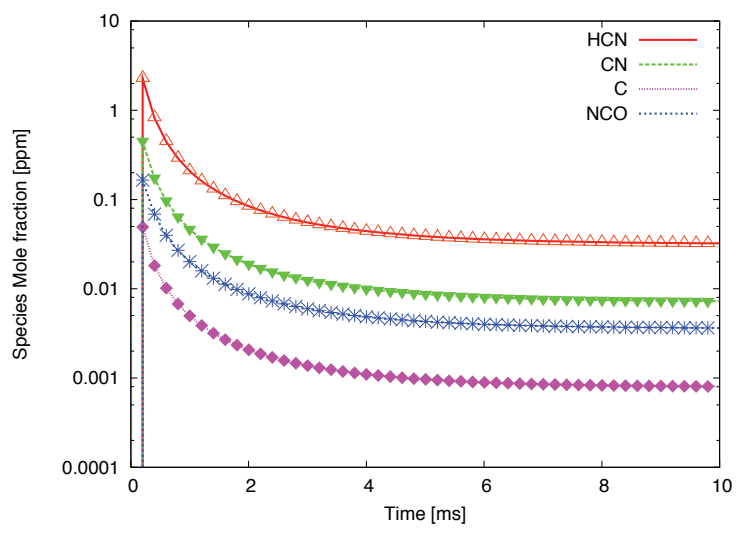

(c) Low concentration species

Figure 8. Comparison of a full (lines) and a reduced (symbols) model for flight-like surface conditions $(\mathrm{T}=$ $5000 \mathrm{~K}$ and $\mathrm{P}=0.01 \mathrm{~atm})$ 


\section{Conclusion}

As part of a continuing project to improve heat and ablation rate modeling on hypersonic re-entry vehicles, an evaluation of three published carbon-phenolic-in-air chemistry models was performed, using a representative and very extreme trajectory point of the Stardust re-entry vehicle. The results showed enormous discrepancy in the boundary layer composition as well as in the convective heat flux. Radiative heat flux proved also to be affected by the choice of model. The discrepancy between the results clearly shows the need to develop a more comprehensive chemistry model that would still be efficient enough to run in a hypersonic CFD code.

\section{Acknowledgments}

Financial support for this work was provided provided in part by NASA SBIR Phase-1 Award NNX10CC53P as well as through NASA Prime Contract NNA04BC25C to ELORET Corporation. The authors would also like to thank Dr. Mike Wright, Dr. Ioana Cozmuta and Dr. Tahir Gökçen from NASA Ames, and Christopher Jonhston from NASA Langley, for numerous insightful discussions. Finally, the authors would like to thank the Michigan Institute for Plasma Science 83 Engineering (MIPSE) and Professor Mark J. Kushner for providing some of the computational resources needed for this project.

\section{References}

\footnotetext{
${ }^{1}$ Suzuki, T., Sawada, K., Yamada, T., and Inatani, Y., "Experimental and Numerical Study of Pyrolysis Gas Pressure in Ablating Test Piece," Journal of Thermophysics and Heat Transfer, Vol. 19, No. 3, July-September 2005, pp. $266-272$.

${ }^{2}$ Dec, J. A. and Braun, R. D., "An Approximate Ablative Thermal Protection System Sizing Tool for Entry System Design," 44th AIAA Aerospace Sciences Meeting and Exhibit, No. AIAA 2006-780, Reno, NV, 9-12 January 2006.

${ }^{3}$ Ayasoufi, A., Rahmani, R. K., Cheng, G., Koomullil, R., and Neroorkar, K., "Numerical Simulation of Ablation for Reentry Vehicles," 9th AIAA/ASME Joint Thermophysics and Heat Transfer Conference, No. AIAA 2006-2908, San Francisco, CA, June 5-8 2006.

${ }^{4}$ Amar, A. J., Blackwell, B. F., and Edward, J. R., "One-Dimensional Ablation with Pyrolysis Gas Flow Using a Full Newton's Method and Finite Control Volume Procedure," 39th AIAA Thermophysics Conference, No. AIAA-2007-4535, Miami, FL, 25-28 June 2007, p. 41.

${ }^{5}$ Milos, F. and Chen, Y.-K., "Two-Dimensional Ablation, Thermal Response and Sizing Program for Pyrolyzing Ablators," 46th AIAA Aerospace Sciences Meeting and Exhibit, AIAA-2008-1223, Reno, NV, Jan. 7-10 2008, p. 7.

${ }^{6}$ Venkatachari, B. S., C.Cheng, G., P.Koomullil, R., and Ayasoufi, A., "Computational Tools for Re-entry Aerothermodynamics - Part II. Surface Ablation," 46th AIAA Aerospace Sciences Meeting and Exhibit, AIAA-2008-1218, Reno, NV, Jan. 7-10 2008.

${ }^{7}$ Martin, A. and Boyd, I. D., "Simulation of pyrolysis gas within a thermal protection system," 40th AIAA Thermophysics Conference, No. AIAA-2008-3805, Seattle, WA, June 23-26 2008, p. 20.

${ }^{8}$ Park, C., Jaffe, R. L., and Partridge, H., "Chemical-Kinetic Parameters of Hyperbolic Earth Entry," Journal of Thermophysics and Heat Transfer, Vol. 15, No. 1, January- March 2001, pp. 76-90.

${ }^{9}$ Suzuki, K., Kubota, H., Fujita, K., and Abe, T., "Chemical nonequilibrium ablation analysis of MUSES-C super-orbital reentry capsule," 32nd AIAA Thermophysics Conference, No. AIAA-1997-2481, June 23-25 1997.

${ }^{10}$ Olynick, D., Chen, Y.-K., and Tauber, M. E., "Aerothermodynamics of the Stardust Sample Return Capsule," Journal of Spacecraft and Rockets, Vol. 36, No. 3, May-June 1999, pp. 442-462.

${ }^{11}$ Martin, A., Boyd, I. D., Cozmuta, I., and Wright, M. J., "Chemistry model for ablating carbon-phenolic material during atmospheric re-entry," 48th AIAA Aerospace Sciences Meeting and Exhibit, No. AIAA-2010-1175, Orlando, FL, January 2010.

${ }^{12}$ Scalabrin, L. C. and Boyd, I. D., "Numerical Simulations of the FIRE-II Convective and Radiative Heating Rates," 39th AIAA Thermophysics Conference, No. AIAA-2007-4044, Miami, FL, 25 - 28 June 2007, p. 17.

${ }^{13}$ Scalabrin, L. C., Numerical Simulation of Weakly Ionized Hypersonic Flow Over Reentry Capsules., Ph.D. thesis, The University of Michigan, Ann Arbor, MI, 2007.

${ }^{14}$ Scalabrin, L. C. and Boyd, I. D., "Development of an Unstructured Navier-Stokes Solver for Hypersonic Nonequilibrium Aerothermodynamics," 38th AIAA Thermophysics Conference, No. AIAA-2005-5203, Toronto, Ontario, June 6-9 2005, pp. $1-18$.

${ }^{15}$ Scalabrin, L. C. and Boyd, I. D., "Numerical Simulation of Weakly Ionized Hypersonic Flow for Reentry Configurations," 9th AIAA/ASME Joint Thermophysics and Heat Transfer Conference, No. AIAA-2006-3773, San Francisco, CA, June 5-8 2006 , p. 18.

${ }^{16}$ Holman, J. P., Heat transfer, Mc Graw-Hill : Publishing Company, 1990.

${ }^{17}$ Wright, M. J., Candler, G. V., and Bose, D., "Data-Parallel Line Relaxation method for the Navier-Stokes equations," AIAA Journal, Vol. 36, No. 9, September 1998, pp. 1603-1609.

${ }^{18}$ Gnoffo, P. A., "Upwind-Biased, Point-implicit Relaxation Strategies for Viscous Hypersonic Flows," 9th AIAA Computational Fluid Dynamics Conference, No. AIAA-1989-1972-CP, Buffalo, NY, June 13-15 1989, pp. 415-425.
} 
${ }^{19}$ Martinelli, S. and Ruffin, S., "Validation Process for Blowing and Transpiration-Cooling in DPLR," 39th AIAA Thermophysics Conference, No. AIAA-2007-4255, 2007, p. 9.

${ }^{20}$ Thompson, R. A. and Gnoffo, P. A., "Implementation of a Blowing Boundary Condition in the LAURA Code," 46th AIAA Aerospace Sciences Meeting and Exhibit, No. AIAA-2008-1243, Reno, NV, Jan. 7-10 2008, p. 11.

${ }^{21}$ Martin, A. and Boyd, I. D., "Implicit implementation of material response and moving meshes for hypersonic re-entry ablation," 47th AIAA Aerospace Sciences Meeting and Exhibit, No. AIAA-2009-0670, Orlando, FL, Jan. 5-8 2009.

${ }^{22}$ Park, C., Nonequilibrium Hypersonic Aerothermodynamics, Wiley-Interscience, February 1990.

${ }^{23}$ Park, C., Howe, J. T., Jaffe, R. L., and Candler, G. V., "Review of Chemical Kinetic Problems of Future NASA Missions, II: Mars Entries," Journal of Thermophysics and Heat Transfer, Vol. 8, No. 1, March 1994, pp. 9-23.

${ }^{24}$ Baulch, D. L., Drysdale, D. D., , and Horne, D. G., Evaluated Kinetic Data for High Temperature Reactions, Volume 1, Homogeneous gas phase rections of the $\mathrm{H}_{2}-\mathrm{O}_{2}$ system, CRC Press, Boca Raton, FL, 1972.

${ }^{25}$ Bose, D. and Candler, G. V., "Thermal rate constants of the $\mathrm{N}[$ sub 2$]+\mathrm{O}-i \mathrm{NO}+\mathrm{N}$ reaction using ab initio [sup 3]A[double-prime] and [sup 3]A[prime] potential energy surfaces," The Journal of Chemical Physics, Vol. 104, No. 8, 1996, pp. 2825-2833.

${ }^{26}$ Bose, D. and Candler, G. V., "Thermal rate constants of the $\mathrm{O}[$ sub 2] $+\mathrm{N}-i \mathrm{NO}+\mathrm{O}$ reaction based on the A[prime]and A[prime] potential-energy surfaces," The Journal of Chemical Physics, Vol. 107, No. 16, 1997, pp. 6136-6145.

${ }^{27}$ Gupta, R. N., Yos, J. M., Thompson, R. A., and Lee, K.-P., "A review of reaction rates and thermodynamic and transport properties for an 11-species air model for chemical and thermal nonequilibrium calculations to $30000 \mathrm{~K}$," Tech. Rep. NASA-RP-1232, NASA Langley Research Center, 1989.

${ }^{28}$ Song, D. J. and Lewis, C. H., "Hypersonic Finite-Rate Chemically Reacting Viscous Flows over an Ablating Carbon Surface," Journal of Spacecraft, Vol. 23, No. 1, Jan.-Feb. 1986, pp. 47-54.

${ }^{29}$ Blottner, F. G., "Prediction of electron density in the boundary layer on entry vehicles with ablation," The entry plasma sheath and its effects on space vehicle electronmagnetic systems: Volume 1, No. NASA SP-252, NASA Langley Research Center, Hampton, Virginia, October 13-15 1970.

${ }^{30}$ Heicklen, J., "Gas-phase chemistry of re-entry." AIAA Journal, Vol. 5, No. 1, 1967, pp. 4-15.

${ }^{31}$ Westbrook, C. K., Pitz, W. J., and Urtiew, P. A., "Chemical Kinetics of Propane Oxidation in Gaseous Detonations," 9th International Colloquium on Dynamics of Explosionsand ReactiveSystems (ICODERS), University of Poitiers, France, 4-8 July 1983.

${ }^{32}$ Bhutta, B. A. and Lewis, C. H., "A New Technique for Low-to-High Altitude Predictions of Ablative Hypersonic Flow Fields," Journal of Spacecraft and Rockets, Vol. 29, No. 1, 1992, pp. 35-50.

${ }^{33}$ Sangisvanni, J. J. and Barber, T. J., "Role of Hydrogen/Air Chemistry in Nozzle Performances for Hypersonic Propulsion System," Journal of Propulsion and Power, Vol. 1, No. 1993, 9, pp. 178-183.

${ }^{34}$ Wilson, J., "Ionization Rates of Air Behind High Speed Shock Waves," Physics of Fluids, Vol. 9, No. 10, 1966, pp. 19131921.

${ }^{35}$ Trumble, K. A., Cozmuta, I., Sepka, S., and Jenniskens, P., "Post-flight Aerothermal Analysis of the Stardust Sample Return Capsule," 46th AIAA Aerospace Sciences Meeting and Exhibit, AIAA-2008-1201, Reno, NV, Jan. 7-10 2008.

${ }^{36}$ Kee, R. J., Rupley, F. M., Miller, J. A., Coltrin, M. E., Grcar, J. F., Meeks, E., Moffat, H. K., Lutz, A. E., Dixon-Lewis, G., Smooke, M. D., Warnatz, J., Evans, G. H., Larson, R. S., Mitchell, R. E., Petzold, L. R., Reynolds, W. C., Caracotsios, M., Stewart, W. E., Glarborg, P., Wang, C., McLellan, C. L., Adigun, O., Houf, W., Chou, C. P., Miller, S. F., Ho, P., Young, P. D., Young, D. J., Hodgson, D. W., Petrova, M. V., and Puduppakkam, K. V., "CHEMKIN, Release 4.1," 2006.

${ }^{37}$ Whiting, E. E., Park, C., Liu, Y., Arnold, J. O., and Paterson, J. A., "NEQAIR96, Nonequilibrium and Equilibrium Radiative Transport and Spectra Program: User's Manual," Reference Publication 1389, NASA, December 1996.

${ }^{38}$ Eldred, M., Brown, S., Adams, B., Dunlavy, D., Gay, D., Swiler, L., Giunta, A., Hart, W., Watson, J.-P., Eddy, J., Griffin, J., Hough, P., Kolda, T., Martinez-Canales, M., and Williams, P., "DAKOTA, A Multilevel Parallel Object-Oriented Framework for Design Optimization, Parameter Estimation, Uncertainty Quantification, and Sensitivity Analysis: Version 4.0," Technical reports, Sandia National Laboratories, September-October 2006. 